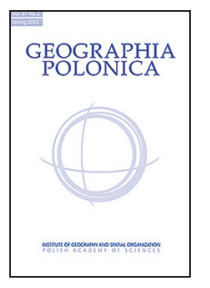

\title{
POLITICAL AND ADMINISTRATIVE BOUNDARIES OF THE GERMAN STATE IN THE 2OTH CENTURY ${ }^{\star}$
}

\author{
Piotr Eberhardt \\ Institute of Geography and Spatial Organization \\ Polish Academy of Sciences \\ Twarda 51/55, 00-818 Warsaw: Poland \\ e-mail: p.ebe@twarda.pan.pl
}

\begin{abstract}
The paper presents the changes in the political and administrative boundaries of the German state, which took place during the 20th century. The starting point is constituted by the political pattern having developed after the establishment of the German Empire in 1871, this pattern lasting until the World War I. Then, the territorial consequences are considered of the decisions, taken at the Versailles Peace Conference. After the presentation of the situation existing during the inter-war period, the political transformations are shown of the annexation politics of the Nazi Germany. The final part of the paper is devoted to the territorial effects that the Potsdam Treaty brought for the defeated Germany.
\end{abstract}

\section{Key words}

political and administrative boundaries - German Empire - German Republic - Nazi Germany $\bullet$ Versailles Peace Conference $\bullet$ Potsdam Treaty • World War I • World War II

\section{Germany before the World War I}

The German Empire, established in 1871 after the victorious war with France, had a very complicated political and administrative structure. It was composed of numerous administrative units, having quite diverse magnitudes and political ranks. These units had taken shape in a long historical process, through various events and political agreements. They

\footnotetext{
* Polish version of the paper was published in 2013 in Czasopismo Geograficzne (see Eberhardt 2013).
}

were often yet the consequences of the feudal breakdown of the German Reich. These elements of historical heritage were very strongly embedded in the consciousness of the Germans, and the attempts of eliminating them encountered both formal and mental obstacles. These were the reasons why, after January 18th, 1871, when the King of Prussia, Wilhelm I, was crowned as the German Emperor, the existing political and administrative division of the country was preserved. This fact had to a large extent a symbolic meaning, since, after the introduction of the new legal 
regulations, the emperor and the central authority in Berlin gained superior constitutional competences. Such a situation constituted the starting point to the integration processes, aiming at the formation of a strongly centralised state with imperial ambitions. Thus, Germany preserved the traditional divisions and internal boundaries, but their significance dwindled to a mere façade. The Pan-German movement, calling for the German unity over the existing divisions, gained an increasing social support, and its goal was to establish a unitary German state. Realisation of this goal required a longer time period, since the feeling of local identity was on numerous areas of the German Reich quite strong, and the authorities of lower levels cultivated the attributes of independence and disposed of significant competences, especially in the domains of culture, education and economy. The central authorities respected the majority of these various rights, not seeing in them any serious threat, meaning primarily the potential weakening of the military power of the German state.

There were four kingdoms within the territory of the German Empire: Prussia, Bavaria, Saxony and Württemberg (Königreich Preussen, Bayern, Sachsen, Württemberg), six Grand Duchies: of Baden, Hesse, Mecklenburg-Schwerin, Mecklenburg-Strelitz, SaxeWeimar-Eisenach (since 1877: of Saxony), and Oldenburg (Grossherzogtum Baden, Hessen, Mecklemburg-Schwerin, Mecklemburg-Strelitz, Sachsen-Weimar-Eisenach, Oldenburg), five Duchies (since 1876, when the Duchy of SaxeLauenburg was incorporated into the Kingdom of Prussia): Brunswick, Saxe-Meiningen, Saxe-Altenburg, Saxe-Coburg and Gotha, and Anhalt (Herzogtum Braunschweig, Sachsen-Meiningen, Sachsen-Altenburg, SachsenCoburg-Gotha, Anhalt), seven principalities (Fürstentum Schwarzburg-Sondershausen, Schwarzburg-Rudolstadt, Waldeck-Pyrmont, Reuss-Greiz älterer Linie - senior line, ReussGera jüngerer Linie - junior line, SchaumburgLippe, Lippe-Detmold), as well as three free Hanseatic cities (Freie Hansestadt): Bremen, Lübeck and Hamburg.
The Kingdom of Prussia, dominating in terms of both magnitude and significance, was composed of the separate city of Berlin, and twelve provinces: East Prussia (Ostpreussen), West Prussia (Westpreussen), Brandenburg, Pomerania (Pommern), Poznań (Posen), Silesia (Schlesien), Saxony (Sachsen), SchleswigHolstein, Hannover, Westphalia (Westfalen), Hesse-Nassau (Hessen-Nassau), and Rhineland (Rheinland).

The German Empire, as it existed until 1918, encompassed 540,800 sq. km, and, according to the census of 1910, was inhabited by 64.9 million people. As said, the Kingdom of Prussia dominated, with its area of 348,700 sq. $\mathrm{km}$, i.e. $64.5 \%$ of the whole Empire. The population share was slightly lower, since it amounted to $61.9 \%$. This fact was associated with the lower population density in eastern parts of Germany. Quite an important part of the entire territory was also taken by the Kingdom of Bavaria. The remaining lands and provinces were smaller and their significance was secondary, even though, taken together, they represented an important demographic and - especially - economic potential (see Tab. 1).

\section{Territorial conquests and losses due to World War I}

When starting the military activities on the fronts of the World War I, German Empire expected to gain significant territorial spoils. It was particularly hoped to defeat Russia and to move far eastward the eastern boundary of the Empire. There was an intention of establishing a large political unit (Mitteleuropa) under the supremacy of Germany, which would include, side by side with Germany and Austria-Hungary, a large portion of the Balkan Peninsula, and the western part of the Russian Empire, encompassing Polish, Lithuanian, Latvian, and Estonian lands, as well as parts of Belarus and Ukraine. ${ }^{1}$

\footnotetext{
1 The German annexation plans with respect to Polish territories are presented in the paper by the same author, Eberhardt (2008).
} 
Table 1. The political and administrative division of Germany in 1910

\begin{tabular}{|c|c|c|c|c|}
\hline No. & Land & Capital & Area in sq. km & Population in 1910 \\
\hline 1 & Prussia & Berlin & $348,702.1$ & $40,156,800$ \\
\hline 2 & Bavaria & Munich & $75,870.2$ & $6,876,500$ \\
\hline 3 & Saxony ${ }^{a)}$ & Dresden & $24,373.6$ & $5,972,100$ \\
\hline 4 & Württemberg & Stuttgart & $19,511.7$ & $2,435,600$ \\
\hline 5 & Baden & Karlsruhe & $15,067.7$ & $2,141,800$ \\
\hline 6 & Hesse & Darmstadt & $7,688.8$ & $1,282,200$ \\
\hline 7 & Mecklenburg-Schwerin & Schwerin & $13,126.9$ & 639,900 \\
\hline 8 & Mecklenburg-Strelitz & Neustrelitz & $2,929.5$ & 106,300 \\
\hline 9 & Oldenburg & Oldenburg & $6,428.8$ & 482,400 \\
\hline 10 & Brunswick & Brunswick & $3,672.1$ & 494,400 \\
\hline 11 & Anhalt & Dessau & $2,299.4$ & 331,000 \\
\hline 12 & Lippe & Detmold & $1,215.2$ & 150,800 \\
\hline 13 & Schaumburg-Lippe & Bückeburg & 340.3 & 46,600 \\
\hline 14 & Schwarzburg ${ }^{\text {b) }}$ & Sondershausen and Rudolstadt & $1,802.5$ & 190,700 \\
\hline 15 & Reuss $^{c)}$ & Gera and Greiz & $1,143.0$ & 225,400 \\
\hline 16 & Waldeck & Arolsen & $1,121.0$ & 61,700 \\
\hline 17 & Alsace and Lorraine ${ }^{d)}$ & Strasbourg and Metz & $14,517.7$ & 1871,700 \\
\hline 18 & City of Lübeck ${ }^{e)}$ & - & 297.7 & 116,600 \\
\hline 19 & City of Bremen ${ }^{f)}$ & - & 256.4 & 298,700 \\
\hline 20 & City of Hamburg ${ }^{g}$ & - & 413.9 & $1,015,700$ \\
\hline \multicolumn{2}{|r|}{ German Empire } & Berlin & $540,778.5$ & $64,896,900$ \\
\hline
\end{tabular}

a) jointly Kingdom of Saxony with its capital in Dresden, and separate duchies: Saxe-Weimar-Eisenach, Saxe-Meiningen, Saxe-Altenburg, Saxe-Coburg and Gotha.

b) Schwarzburg-Sondershausen and Schwarzburg-Rudolstadt.

c) The duchies of Reuss junior line, with its capital in Gera, and Reuss senior line, with its capital in Greiz.

d) The Imperial Land of Alsace and Lorraine, with the capital in Strasbourg, while the capital of Lorraine was in Metz.

e) Free city of Lübeck.

f) Free city of Bremen.

g) Free city of Hamburg.

Source: Die Bevölkerung des ... (1912).

In the initial phase of the World War I, after the conquest of Belgium and north-eastern France, the German occupational authorities made their annexation demands more precise. Thus, it was assumed at the beginning to take away from France the area of Belfort (608 sq. km) and the district of Longwy-Briey $(5,280 \mathrm{sq} . \mathrm{km})$, and thereafter - to go on with the annexation of Luxembourg, with addition of lands, belonging to Belgium, up to the line of river Meuse. In the expectation of the ultimate victory, maximum annexation plans were also formulated, which included the area of 27,000 sq. km, inhabited by the French population. This area included also three French havens (Dunkirk, Calais and Boulogne).

When the situation on the western front worsened, it became obvious that the plans of pushing westwards this boundary of the German Reich are not realistic and closer to the end of the war it was assumed that the status quo ante, that is - the course of boundaries from the 1914 - should be preserved.

The war, contrary to the initial expectations of the German military planners, brought defeat. The military activities on the eastern front ended apparently with a success, as confirmed in the Treaty of Brest. This success, 
Table 2. Territorial losses of Germany owing to the World War I

\begin{tabular}{|c|l|c|c|}
\hline No. & Losses to the advantage of & Area in sq. km & Population in 1910 \\
\hline 1 & Poland & 46,142 & $3,855,000$ \\
2 & France & 14,522 & $1,874,000$ \\
3 & Denmark & 3,993 & 166,000 \\
4 & Lithuania & 2,657 & 141,000 \\
5 & Free City of Gdańsk & 1,951 & 331,000 \\
6 & Belgium & 1,036 & 60,000 \\
7 & Czechoslovakia & 316 & 48,000 \\
\hline \multicolumn{2}{|c}{ Total } & 70,617 & $6,475,000$ \\
\hline
\end{tabular}

Source: Riedel (1928: 47).

though, turned out to be only transitory, and the ultimate decisions as to the fate of Germany were taken during the peace conference in Versailles.

These decisions, taken with respect to Germany in Versailles, were very hard. Germany lost all of its colonies and bore territorial losses to the advantage of the neighbouring countries: Poland, France, Denmark, Lithuania, Belgium and Czechoslovakia. In addition, the Free City of Gdańsk, separated from Germany, was established (see Tab. 2).

The most painful territorial losses occurred in the east. In consequence of reappearance of independent Poland, Germany lost almost entire region of Wielkopolska (roughly equivalent to the province of Posen), and then a large portion of Pomerania. The new Polish-German divide within this area had a course similar to the historical one from 1772, i.e. before the partitions of Poland. There were some differences to the advantage of Poland with respect to the historical line, in the vicinity of Namysłów and Rawicz, but also to the advantage of Germany - in the areas of Kargowa, Nowe Kramsko, Santok and Drezdenko. Poland gained, in particular, the towns on the eastern side of Vistula, such as Brodnica, Grudziadz, Torun and Lubawa, and on the western side: Chojnice, Sępolno, Kartuzy, Kościerzyna, Tczew, and Puck in the North.

At a later date, already after the Paris Conference, having taken place in Versailles, the decision of the Conference of Ambassadors determined the Polish-German boundary on the areas, where plebiscites had been organised. These plebiscites were announced, successively, on August 12th, 1920, for Warmia, on August 15th, 1920, for Mazuria (both being parts of the former East Prussia), and then on October 20th, 1921, for Upper Silesia. It was only in this last case that the verdict was not fully advantageous for Germany².

Thus, on the basis of the decision, taken by the western allies on May 7th, 1919, Poland was to acquire almost entire province of Poznań (except for the county of Skwierzyna and the parts of the counties of Wschowa, Babimost, Międzyrzecz, Wieleń and Czarnków), an important part of West Prussia, situated on the left hand side of Vistula (with exception of the counties of Wałcz and Człuchów, and parts of the counties of Złotów and Lębork), and an edge of East Prussia. Hence, East Prussia, separated from the main territory of Germany by the Polish 'corridor', became an enclave, constituting, however, an integral part of the German state . $^{3}$.

More acute economic losses were associated with the incorporation to Poland of the eastern part of Upper Silesia, including

\footnotetext{
${ }^{2}$ It must be noted that the first two plebiscites were announced in the instance, when the very existence of the Polish state was threatened, because of the Bolshevik aggression - on exactly this particular moment the advance of the Bolshevik troops was at its highest reach.

3 Out of East Prussia, Poland acquired only the county of Działdowo, and some single border-adjacent villages.
} 
Chorzów (Królewska Huta - Königshütte), Katowice, and Rybnik. The overall territorial loss to the advantage of Poland amounted to $46,100 \mathrm{sq} . \mathrm{km}$, of which $4,200 \mathrm{sq} . \mathrm{km}$ in Silesia, 26,000 sq. km out of the - roughly - former province of Poznań, and 15,900 sq. km in Pomerania. ${ }^{4}$

Due to the verdict of Versailles, Germany was forced to give up a large portion of Alsace and Lorraine, having 14,500 sq. km of area. These were exactly the areas, incorporated on the basis of the Frankfurt Treaty in 1871 into the German Empire. They were inhabited mainly by the population speaking German dialects, but to a large extent associated with French culture. Owing to the shift of this boundary, the eastern border of France moved over to the line of Rhine. Side by side with the symbolic meaning, this also had a strategic importance. Besides, France was given the right to temporarily occupy Rhineland and the Saar Basin. The latter returned to the Reich only in 1935, after an advantageous result of the plebiscite, carried out there.

Quite significant boundary shift took place on the Jutland Peninsula. The northern part of the historical province of Schleswig-Holstein was incorporated into Denmark. Since the Danish-Prussian war (1864) this area belonged to Germany. On the basis of the plebiscite, the area of some 4,000 sq. km, with towns such as Hadersleben, Sonderburg, Apenrade and Tondem, became a part of Denmark.

There was also a change of the BelgianGerman boundary, where two areas, only thinly separated - Eupen and Malmedy, were taken away from Germany and incorporated in Belgium. Population of these areas was predominantly speaking German, and so, incorporation into Belgium constituted to an extent a compensation for the losses, borne by Belgium due to the German invasion

\footnotetext{
${ }^{4}$ According to Polish data, the territorial losses of Germany to the advantage of Poland were slightly bigger, amounting, approximately, to $47,100 \mathrm{sq}$. km, with breakdown into Wielkopolska - 26,500 sq. km, Pomerania - 15,600 sq. km, Upper Silesia - 4,200 sq. km, and the county of Działdowo - 800 sq. km (Historia Polski... 2003: 259; Mały Rocznik Statystyczny 1937: 14).
}

and the fighting in the first stage of the war. These two areas had the total surface of some $1,000 \mathrm{sq}$. km. Besides, a small territory of Moresnet with the township of Kelmis, not far from Aachen, was also ultimately incorporated into Belgium.

Another decision, taken in Versailles, concerned the so-called land of Klaipeda (German Memel - Memelgebiet or Memelland). This area, to the North of river Neman, was inhabited by the population speaking either German or Lithuanian language. They were mostly of Lithuanian extraction, but, owing to the fact that they were of Protestant religion, they opted for the incorporation into the German state. This area was supposed to remain under the supervision of the allies, but, eventually, was in 1923 incorporated into Lithuania. It had some 2,600 sq. km of area, with roughly 150,000 inhabitants.

The status of the Free City of Gdańsk, established in Versailles on the area of some 1,900 sq. km, was highly complicated. This territory was inhabited by the population that was in a vast majority German speaking and of German nationality. Yet, Poland also acquired quite significant competences with respect to this, formally independent, territory.

Based on the decision of the allied powers, the land of Hlučin, being a part of the historical Principality of Ratibor (Racibórz), was incorporated into Czechoslovakia, despite the protests of the local population. This area belonged since 1742 to Kingdom of Prussia, and was inhabited by the mixed GermanCzech (Moravian-Silesian) population of quite unstable national identity. This small territory of some $300 \mathrm{sq}$. $\mathrm{km}$ was situated within the borderland of three ethnic areas: Czech, Polish and German.

\section{The period between 1918 and 1937}

Because of defeat in World War I, Germany lost the area of more than $70,000 \mathrm{sq} . \mathrm{km}$, equivalent to $15.1 \%$ of the previous territory of Germany. The loss in terms of population number, resulting from the boundary changes, amounted to approximately 6.5 million. 
These losses were painful and were made use of by the nationalist groups in the proclamation of the 'unfair' Versailles verdict, which had hurt the German people in an unjustified manner and enforced disadvantageous political boundaries. The revisionist propaganda was primarily oriented against Poland, since $65 \%$ of the territory, lost by Germany, became Polish (Hauser 1995).

The disappearance of the German Empire and the establishment of the German Republic had the essential consequences in terms of the political system and the principles of functioning of the state. All of the feudal remnants in the form of numerous kingdoms, duchies, principalities, etc. were liquidated. Yet, the existing territorial division was, in principle, preserved, including the large, medium, and small historical provinces. There were only limited modifications of the internal administrative boundaries, aimed at increasing the effectiveness of functioning of the administrative units and adaptation to the requirements of the modern times. Conform to the changes in the political system, they took on the republican character, while preserving many of the long established self-governmental competences, concerning internal affairs, mainly in education and the judicial matters. The state had formally a federal character, but, actually, the universalist and centralist tendencies have been intensifying. This, however, was taking place with maintenance of the legality and the democratic order. It was only after the so-called Weimar Republic collapsed and Adolf Hitler came to power, that the state assumed a dictatorial and totalitarian character, with the regional authorities having lost all the possibilities of autonomous activity.

Like before the Great War, the largest part of the German territory belonged to Prussia, with its area of 293,200 sq. $\mathrm{km}$. In relation to the imperial period, this area decreased by $55,500 \mathrm{sq} . \mathrm{km}$, which was mainly due to the losses to the advantage of Poland. The territory of Prussia was divided into provinces and regencies. Bavaria, where definite separatist tendencies were present, also occupied still quite an important territory (Tab. 3).

\section{Territorial expansion in the period preceding World War II}

During the period of strengthening of the military power of the Nazi 3rd German Reich, the revision of the decisions, taken at the Versailles treaty became the key political objective. This objective would constitute a very convenient pretext for the potential further territorial annexations. The initial step towards this objective was the entering of the German troops into Rhineland. This act encountered no reaction from the side of France or England. The next step in the violation of the international agreements consisted in the 'Anschluss' of Austria to the 3rd German Reich. At the orders of Hitler, on March 12th, 1938, Wehrmacht entered Austria, and a day later Austria was already renamed East Mark (Ostmark) (Zgórniak 1966). Later on, this area took the name of Alpen und Donaugaue. The territory of the Reich increased by $83,900 \mathrm{sq} . \mathrm{km}$, and the population number - by 6.5 million people.

The subsequent annexation was associated with the incorporation of the Land of Klaipeda. This sole coastal province and sole seaport of Lithuania were taken by the Nazi Germany on March 23rd, 1938, as the result of an ultimatum, issued by Adolf Hitler and accepted by the Lithuanian authorities. The area of 2,600 sq. km was directly incorporated into East Prussia (Łossowski 2007).

After these successes the 3rd Reich started to exert political pressure on Czechoslovakia. In the consequence of the events, associated with the Munich Conference (September 30th, 1938), Hitler gained the acceptance for the incorporation into the 3rd Reich of the so-called Czech Borderland. As a result of this dictate, Czechoslovakia lost $28,971 \mathrm{sq}$. $\mathrm{km}$ of its territory, having belonged to Bohemia and Moravia, inhabited by 3.5 million people, including 2.8 million Germans and 0.7 million Czechs. The 'borderland' was included into the 3rd Reich on October 31st, 1938, as Sudetengau.

A couple of months later, on March 15th, 1939, Hitler violated the stipulations of the Munich Conference and occupied the 
Table 3. The political and administrative division of Germany in 1925

\begin{tabular}{|c|c|c|c|c|}
\hline No. & Land & Capital & Area in sq. km & Population in 1925 \\
\hline 1 & Prussia & Berlin & 293,186 & $38,878,000$ \\
\hline 2 & Bavaria & Munich & 75,996 & $7,412,000$ \\
\hline 3 & Saxony & Dresden & 14,993 & $4,980,000$ \\
\hline 4 & Württemberg & Stuttgart & 19,508 & $2,595,000$ \\
\hline 5 & Baden & Karlsruhe & 15,071 & $2,336,000$ \\
\hline 6 & Thuringia & Weimar & 11,724 & $1,628,000$ \\
\hline 7 & Hesse & Darmstadt & 7,693 & $1,358,000$ \\
\hline 8 & Hamburg & Hamburg & 415 & $1,129,000$ \\
\hline 9 & Mecklenburg-Schwerin & Schwerin & 13,127 & 688,000 \\
\hline 10 & Mecklenburg-Strelitz & Neustrelitz & 2,930 & 112,000 \\
\hline 11 & Oldenburg & Oldenburg & 6,424 & 554,000 \\
\hline 12 & Brunswick & Braunschweig & 3,672 & 509,000 \\
\hline 13 & Anhalt & Dessau & 2,299 & 352,000 \\
\hline 14 & Bremen & Bremen & 256 & 333,000 \\
\hline 15 & Lippe & Detmold & 1,215 & 166,000 \\
\hline 16 & Lübeck & Lübeck & 298 & 128,000 \\
\hline 17 & Waldeck & Arolsen & 1,055 & 59,000 \\
\hline 18 & Schaumburg-Lippe & Bückeburg & 340 & 49,000 \\
\hline \multicolumn{2}{|r|}{ Germany } & Berlin & $468,718^{a)}$ & $62,593,000$ \\
\hline
\end{tabular}

a) In the cited source, the total area of Germany amounts to $468,718 \mathrm{sq}$. km, while summation of areas of the particular provinces yields the area of 470,202 sq. km. The difference, though, appears to have no essential significance. Source: Riedel (1928: 46).

remaining areas of Bohemia and Moravia, and then, on March 16th, 1939, issued a decree, establishing the so-called Protectorate of Bohemia and Moravia, which became an integral part of the 3rd German Reich. Thereby, the territory of the German state increased by 48,900 sq. km (Bohemia - 33,200 sq. km, Moravia - 16,700 sq. km), and its population - by 7.38 million persons (Majewski 2001).

\section{The period of World War II (1939-1945)}

The subsequent territorial annexations were linked already with the necessity of undertaking military aggression. On the very first day of the war, September 1st, 1939, the Free City of Gdańsk was proclaimed to have become a part of the 3rd Reich. Then, after the defeat of Poland and establishment of the demarcation line with the USSR, which divided the area of Poland (on September 28th, 1939), the entire western and central parts of Poland were occupied by the Nazi Germany. By virtue of Hitler's decree of October 8th, 1939, the provinces of Pomerania and Poznań, a part of the province of Łódź (later on renamed by the Germans to Litzmannstadt), Upper Silesia, Basin of Dabrowa Górnicza, western counties of the province of Kraków, northern part of the province of Warsaw (district of Ciechanów) and northern part of the region of Suwatki - were all incorporated formally directly into Germany.

This area, formally incorporated into Germany, was equal 91,900 sq. km, and, according to estimates, was inhabited by altogether $10,570,000$ persons. The territory in question was divided into the Reich provinces (-gau), namely: Gdańsk-West Prussia (Reichsgau Danzig-Westpreussen) and the Land of (river) Warta (Reichsgau Wartheland or Warthegau). 
These units, in turn, were composed of districts and regencies. Of the areas of Upper Silesia and the western counties of the province of Kraków, in March 1941, the separate Upper Silesian regency was formed, with the capital in Katowice. Northern Masovia was incorporated into the province of East Prussia as the regency of Ciechanów, while a part of the region of Suwałki was included in the Regency of Gabin (Gumbinnen).

On the basis of Hitler's decision of October 12th, 1939, the remaining territories of Poland, which were not directly incorporated into the Reich, formed the so-called General Governorship, with the capital in Kraków. This unit was subdivided into four districts: Kraków, Lublin, Radom, and Warsaw. The area of General Governorship was 95,700 sq. km and was inhabited by $11,540,000$ persons (Historia... 2003: 261).

During just two years (1938-1939) the territory of the 3rd German Reich increased at the expense of Austria by $83,900 \mathrm{sq}$. km, of Czechoslovakia - by 77,900 sq. km, of Lithuania - by 2,600 sq. km, of the Free City of Gdańsk - by 1,900 sq. km, and of Poland - by 187,600 sq. km. Thus, altogether, the territory of the Reich increased by $354,100 \mathrm{sq} . \mathrm{km}$. Since the area of Germany before these annexations was $468,700 \mathrm{sq}$. $\mathrm{km}$, so - after them it amounted to $822,800 \mathrm{sq}$. $\mathrm{km}$. This territory stretched from the Rhine river up to Neman and Bug rivers. The demographic potential of this vast territory, subordinated to the Nazi Germany at the turn of 1940 is estimated to be equal close to 110 million. The calculations here reported find the confirmation in the official German data as of December 31st, 1939, stating, namely that the area was equal 823,481 sq. $\mathrm{km}$, and the population, inhabiting it - 109.5 million (or, literally, 109,518,200 persons) (Perthes 1941: 35).

On May 10th, 1940, Hitler attacked France and in a true 'blitzkrieg' caused its military collapse in just a couple of weeks. On June 22 nd, 1940, in Rethondes, in exactly the same place, where the World War I ended in the West, the armistice was signed between Germany and France. Thus, revenge was complete - not only Alsace and Lorraine were again taken away from France, but further annexations were made, and also the German-Belgian boundary returned to its course from before the Versailles Treaty. Along with Alsace $(8,294 \mathrm{sq} . \mathrm{km})$ and Lorraine $(6,224 \mathrm{sq} . \mathrm{km})$ also the departments of $\operatorname{Nord}(5,774$ sq. $\mathrm{km})$ and Pas-de-Calais $(6,752 \mathrm{sq}$. km) were subordinated to the German military administration.

The subsequent victim of the German aggression was Yugoslavia, which, after having been defeated in April 1941, was territorially dismembered. A relatively big Croat state was established. This became the way to the annexation of a part of Slovenian lands. The areas, situated to the South of Mura river, that is the so-called Southern Styria (Südsteiermark), of roughly 3,000 sq. km and 200 thousand inhabitants, was incorporated into the 3 rd Reich. Its capital was in Maribor (Marburg). It was extended by a small part of Krajna (Oberkrain), having the area of 1,000 sq. km and the population of 40 thousand persons.

Aggression of the German Wehrmacht army against the Soviet Union on June 22nd, 1941, allowed for the successive annexations and boundary shifts. The essential decisions, concerning the occupied territories, situated on the eastern side of the German-Soviet demarcation line, which belonged until 1939 to Poland, and in the period 1939-1941 were under the Soviet occupation, were taken on July 16th and August 15th, 1941. The district of Białystok was established, having $32,000 \mathrm{sq} . \mathrm{km}$ and 1.7 million inhabitants, and was incorporated directly into the Reich - subordinated to Erich Koch, the gauleiter (governor) of East Prussia. At the same time the decision was taken of incorporating the entire Eastern Galicia (that is - the eastern part of the Polish province of Lwów, and the provinces of Tarnopol and Stanisławów) into the General Governorship. Thereby, the fifth district was established, called Galicia, with $47,100 \mathrm{sq}$. $\mathrm{km}$ and roughly 4.5 million inhabitants.

The above data indicate that these successive annexations, in the West and South, and then in the East, increased even more 


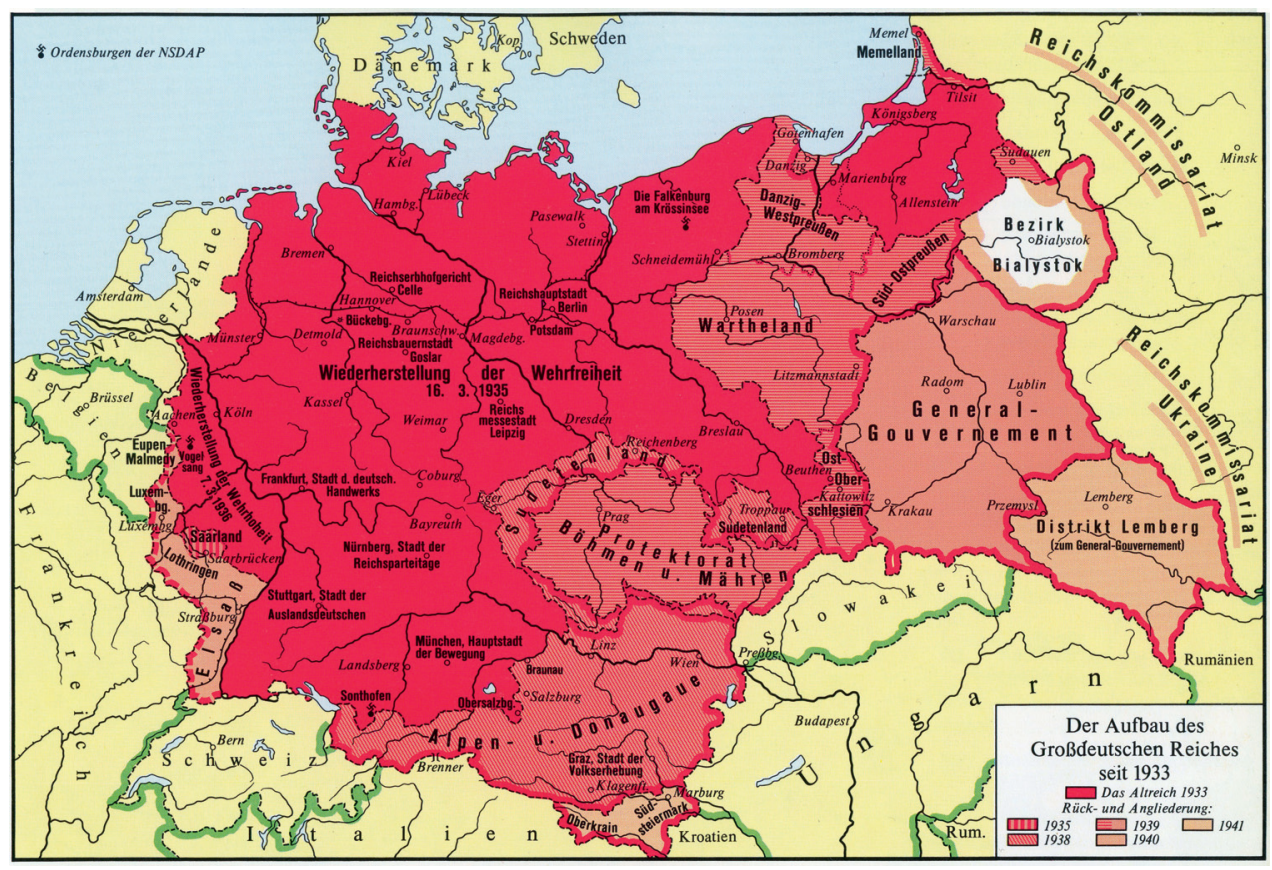

Figure 1. Great Germany and the Lebensraum.

Source: Hilgemann 1984: 131.

significantly the territory of the Great Germany (Grossdeutschland). At the peak of the annexation process, this territory had the area of 920000 sq. km and was inhabited by 118 million persons. In order to illustrate the scale of these annexations, a map is quoted in the present paper from the German atlas of Hilgemann, see Figure 1 (Hilgemann 1984: 131). It must be added here, that the numbers quoted concern the territories formally incorporated into Germany, while the Nazi occupation extended, in fact over a yet much broader area of Europe and beyond.

In view of the relations with Benito Mussolini, German territorial postulates with respect to Italian Upper Adige area, inhabited by the German-speaking population, having belonged until 1918 to Austria, were quite restrained. Officially, Hitler renounced all the claims with respect to the so-called Bolzano province and recognised the boundary along the Brenner Pass as the ultimate one (May 7th, 1938). After the downfall of Mussolini,
Germans did in fact, even though not formally, step back from these promises and at the end of 1943, on all the areas that had belonged to the Hapsburg monarchy in the past, Italian administration was removed. The Italian provinces of Bolzano, Trento and Belluno were named by the Germans the Pre-Alpine Land, while the Istria peninsula - Triest, and the valley of Soča, that is - the Julian Venice - the Adriatic Coast (Wituch 2001).

\section{Decisions of the victorious allies regarding Germany}

The great territorial gains, realised in the years 1938-1942, were short-lived. They could have been preserved only in the case of an overwhelming victory of the Nazi Germany on all fronts of the World War II. This was little probable from the very beginning. As it could be expected, the expansionist, aggressive politics, which did not account for the geopolitical, military nor economic realities, 
had to end with a spectacular catastrophe. German armies started to bear defeats and were forced, gradually, to abandon the occupied areas. The ultimate epilogue of more than five years of war was constituted by the unconditional capitulation, which was accepted on May 8th, 1945. The future of Germany was to be decided by the three victorious powers - USSR, USA and United Kingdom. The respective decisions were taken at the Potsdam Conference, on July 17th - August 2nd, 1945 (Kokot 1957; Hartenstein 2006). The initial plans were established before during the conferences in Teheran and Yalta, but these plans were not yet fully binding. The decisions of the leaders of the anti-Nazi coalition, announced in Potsdam, are known, and do not need to be reminded here. Thus, unconditionally, all the territorial changes, imposed by the German authorities after December 31st, 1937, were annulled and deemed invalid. This concerned the annexations, having affected Austria, Czechoslovakia, Lithuania, Poland, Yugoslavia, Belgium and France. At the same time, decisions were made, concerning the territory, contained within the boundaries of the German state, as it existed between the years 1919 and 1937. This particular issue gave rise to certain controversies among the victorious allies, but, finally, a common position was worked out. The eastern boundary of the German state was established along the line of Oder-Neisse rivers (Odra and Nysa Łużycka). The consequence was that the areas to the East of this line shall be taken away form Germany and incorporated into Poland, and partly to the USSR. The city of Szczecin (Stettin), and its closest neighbourhood, situated on the left bank of Odra, was also included in the part, taken away from Germany. The formal ultimate decisions were supposed to be taken at the peace conference, to be held later on, but it turned out that the decisions from the Potsdam Conference assumed, actually, the ultimate character. The remaining territory of the German state was to be divided into four occupation zones (similarly as the city of Berlin by itself), that is, into the Soviet, British, French and American zones.
Establishment of the Polish-German border along the Oder-Neisse rivers line was inseparably associated with the loss to Germany to the advantage of Poland and USSR - of the territory encompassing 114,559 sq. km, having been inhabited before the war, according to German data, by 9,559,700 persons (Knaurs... 1950-51). Later Polish calculations specified that the area, incorporated into Poland, amounted to $102,836 \mathrm{sq}$. km, including the area of the Free City of Gdańsk, that is $-1,893 \mathrm{sq}$. $\mathrm{km}$. This territory was inhabited in 1933 by the population of $8,531,000$ persons (Dziewoński 1967: 54). The area estimates here provided imply that the northern part of East Prussia, which was not incorporated into Poland, but into the USSR (the present day District of Kaliningrad), occupied 11,723 sq. km. The current statistical data for this particular unit, being a part of the Russian Federation, speak of a definitely bigger area (some 15 thousand sq. km). It can be supposed that this difference is due to consideration of the relatively vast water bodies of Vistula and Kuron Lagoons, as integral parts of the area.

Incorporation of the eastern part of Germany into Poland required appropriate administrative changes, since the German divisions and local names were liquidated (Ziemie... 1966). The final decision, ending the temporary status of the respective territories, was taken on May 29th, 1946. Provincial (voivodship) units were established with capitals in Olsztyn (19,300 sq. km), Wrocław $(24,700 \mathrm{sq} . \mathrm{km})$, and Szczecin $(30,300 \mathrm{sq} . \mathrm{km})$. These three provinces coincided in their entirety with the former German territory, incorporated into Poland. A small part of the former East Prussia was included in the province of Bialystok $(2,600 \mathrm{sq}$. $\mathrm{km})$. The newly established province of Gdańsk included also the area of 5,100 sq. km, formerly belonging to Germany, and also the area of the pre-war Free City of Gdańsk (1,900 sq. km). The existing province of Poznań was increased by $11,200 \mathrm{sq} . \mathrm{km}$, and the Silesian province, with capital in Katowice - by 9,700 sq. km (Sienkiewicz \& Hryciuk 2008: 29). All this amounted to a formal incorporation of the 
so-called Regained Lands into the Polish state administration. ${ }^{5}$

Simultaneously with the changes in the outer boundaries of Germany, the division took place of the remaining German territory into four occupation zones. In this process, the previously mentioned historical administrative divisions also underwent modifications. These modifications consisted in the aggregation of the small units and establishment of large provinces, which took on the name of 'Lands' (Länder), the Federal Lands (Bundes Länder). The boundaries between these units were often dramatically altered in comparison with the traditional divisions. In addition, these new internal boundaries had to follow the separation into occupation zones.

After the allies introduced the occupational regime, the boundaries and the units were subject to verification. An exception, regarding these changes, was constituted by Bavaria. The most important change was due to the decision, taken by the Control Council for Germany in 1947, stipulating the liquidation of Prussia, as the entity that embodied the German imperialism. This legal act had, in fact, just a symbolic meaning, since Prussia lost its actual identity in 1933, remaining only nominally a unit inside the 3 rd Reich. Prussia could not be re-established, neither, also because its major historical eastern part was incorporated into Poland (and the USSR), and the remaining western portion was divided up and included in the Soviet, British, and American zones. On the western areas of the former Prussia a new, entirely ahistorical land was created of Northern Rhineland and Westphalia. Then the land of Lower Saxony was established, with the actual capital in Hannover, encompassing also the miniature principalities, such as Lippe and Oldenburg, as well as Schleswig-Holstein, situated in the North. The remaining principalities, such as Kassel and Nassau, were incorporated into the Land

5 The very ample bibliography, concerning the Polish-German boundary, is provided in the classical works of Labuda (1974) and Czubiński, ed. (1992). The latter volume has been subject to a critical assessment in the review by Muszyński (1995). of Hessen. Another new 'Land' that was established, called Rhineland-Palatinate, was composed of the fragments, situated on the left bank of Rhine, having previously belonged to the Bavarian, Prussian, and Hessian provinces. The arbitrary character of the establishment and definition of the new administrative units is well illustrated by the joining of Baden and Württemberg in 1949 in order to establish a new land. This move was formally sanctioned by the plebiscite, which was deemed illegal in Baden (Mann 2007).

Ultimately, the Soviet zone (or sector) encompassed Brandenburg, Mecklenburg, Saxony, Saxony-Anhalt, and Thuringia. The American sector included Bavaria, Hessen, Württemberg-Baden, and the city of Bremen. The British sector encompassed Lower Saxony, Rhineland-Westphalia, Schleswig-Holstein, and the city of Hamburg. Finally, the French sector included Rhineland-Palatinate and Württemberg-Hohenzollern. For all of these new administrative units (Lands) the respective calculations of areas were performed, and population census was carried out in 1946 (see Tab. 4).

American and Soviet sectors had similar areas. The British sector was slightly smaller. The French sector was relatively small. The division into the occupation sectors lasted for quite a short time. The first step away from the initial division consisted in the joining of the British and American zones in 1947, leading to the appearance of the so-called Bizonia (or Bizone). Then, the French sector was added, which led to the establishment of the so-called Trizonia. Afterwards, with the agreement from the western allies, the three western occupation zones formed together the Federal Republic of Germany (on September 7th, 1949). This political entity, of the area of 247000 sq. km, had the provisory capital in Bonn. The process, leading to the establishment of this state, was accelerated by the currency reform (June 20th, 1948), blockade of Berlin by the USSR, and the economic aid in the form of Marshall Plan.

While the boundaries between the western occupation sectors in Germany have been gradually disappearing, the separation from 
Table 4. The division of the German territory into federal lands and occupation sectors according to the state as of 1946

\begin{tabular}{|c|l|c|c|}
\hline No. & Federal lands and occupation zones & Area in sq. km & Population \\
\hline 1 & Brandenburg & 26,976 & $2,527,500$ \\
2 & Mecklenburg & 22,938 & $2,139,600$ \\
3 & Saxony & 16,992 & $5,558,600$ \\
4 & Saxony-Anhalt & 24,669 & $4,160,500$ \\
5 & Thuringia & 15,598 & $2,927,500$ \\
\hline I & Soviet sector & 107,173 & $17,313,700$ \\
\hline 1 & Bavaria & 70,238 & $9,029,100$ \\
2 & Hessen & 21,117 & $4,064,100$ \\
3 & Württemberg-Baden & 15,700 & $3,675,200$ \\
4 & City of Bremen & 404 & 486,500 \\
\hline II & American sector & 107,459 & $17,254,900$ \\
\hline 1 & Lower Saxony & 47,218 & $6,432,800$ \\
2 & Rhineland-Westphalia & 34,076 & $11,797,100$ \\
3 & Schleswig-Holstein & 15,658 & $2,650,500$ \\
4 & City of Hamburg & 747 & $1,424,100$ \\
\hline III & British sector & 97,699 & $22,304,500$ \\
\hline 1 & Baden & 9,952 & $1,197,900$ \\
2 & Rhineland-Palatinate & 19,856 & $2,761,200$ \\
3 & Württemberg-Hohenzollern & 10,407 & $1,118,800$ \\
\hline IV & French sector & 40,215 & $5,077,900$ \\
\hline & Berlin - divided into four sectors & 355,872 & $3,199,900$ \\
& Saar Basin & & $85,002,700$ \\
\hline & Germany & & \\
\hline
\end{tabular}

Source: Knaurs Lexikon A-Z(1950-1951: 298).

the Soviet zone has undergone strengthening. Then, on October 7th, 1949, on the territory of the Soviet zone, the German Democratic Republic was established, having the area of 108300 sq. km, with its capital in East Berlin, i.e. the part of the city of Berlin, occupied by the Soviets. The boundary between the two German states became a very tight barrier, separating two different and inimical political and economic systems. Along this boundary, crossing the very heart of Germany, the armed forces of the two military alliances were concentrated, ready for a potential confrontation. Under the protection from the three western powers, West Berlin was also established, constituting an enclave, territorially separated from the area of the Federal Republic of Germany. Under such circumstances the significance of the Polish-German boundary along the Oder-Neisse rivers line underwent political marginalization. The thus initiated state of the 'cold war' lasted some forty years.

\section{Geopolitical changes of the 1990s}

Owing to the unexpected events, associated with the downfall of communism and the disintegration of the USSR, the possibility arose 
of uniting the two German states. On the basis of the agreement between the People's Chamber of the German Democratic Republic and the Bundestag of the Federal Republic of Germany, on August 31st, 1990, the treaty was ratified on the re-unification of Germany, and on October 3rd, 1990, the German Democratic Republic was officially included in the Federal Republic of Germany. From the point of view of international law, the German Democratic Republic was, in principle, liquidated. The effect of these acts, having the character of treaties, which were acknowledged by the international community, including the Russian Federation, was the sole, united German state.

The great geopolitical transformations entailed the necessity of introducing a uniform administrative and political system on the territory of the freshly expanded country. The territory of the German Democratic Republic had been divided into districts (Kreise), their names being equivalent to their capitals. These units - altogether 15 of them, including Berlin - did not refer to the historical traditions, but constituted the administrative regions of the bigger towns in the country. These towns were: Rostock, Neubrandenburg, Schwerin, Potsdam, Frankfurt am Oder, Magdeburg, Cottbus, Halle, Leipzig, Erfurt, Dresden, Karl-MarxStadt (until 1953: Chemnitz), Gera, Suhl and Berlin. Conform to the constitution of the Federal Republic of Germany these units were liquidated and the uniform division into the Federal Lands (Bundes Länder) was introduced.

Thus, in the post-war eastern Germany the administrative breakdown was, more or less, brought back, which had existed before the division into two independent political entities. The ultimate effect of these changes, which had not have uniquely the procedural character, was the division of the entire country into sixteen Lands. Ten of them composed before 1990 the Federal Republic of Germany, and these ones remained unchanged. Five new Lands were established on the territory of the former German Democratic Republic: Brandenburg, Thuringia, Saxony, Saxony-Anhalt, as well as Mecklenburg-Vorpommern
(Fore-Pomerania). The now united Berlin gained also the status of the Federal Land (see Tab. 5).

The administrative setting, which appeared following the unification, has persisted until today. This setting is relatively balanced, with only slight territorial disparities (if we exclude the three urban units). The differences are much bigger in terms of the demographic potential. These differences are associated with the uneven population density, which, in turn, is linked with the degree of urbanization and industrialization.

The Federal Republic of Germany has fully acknowledged the course of its outer political boundaries. They are treated as valid and undisputable. That is also why the German state does not forward any territorial claims with respect to its neighbours. The decisions, concerning the course of outer boundaries, taken at the Potsdam Conference, proved to be persistent, even though it appeared at the moment they were taken, that their role and validity is only temporary. They are no longer questioned, and they do not give rise to emotions nor reservations. They can only constitute an object of interest for historians, geographers, and specialists in geopolitics.

\section{Conclusions}

During the 20th century the German state changed its political boundaries several times over. This was closely associated with the changes in the magnitude of territory of the state. The overall balance of these changes has been exceptionally disadvantageous for Germany. At the very beginning of the 20th century the then existing German Empire had 540,800 sq. $\mathrm{km}$ of area. After the defeat of the imperial (kaiserliche) Germany in the World War I, under the Treaty of Versailles, this area shrunk to $468,700 \mathrm{sq}$. $\mathrm{km}$. So, the territorial losses amounted to 72100 sq. km (according to some other calculations: $70,600 \mathrm{sq} . \mathrm{km}$ ). This was the origin for the undertaking of the revenge politics, with its epilogue, constituted by the World War II. Despite the initial spectacular successes, this war ended, again, 
Table 5. Political and administrative division of the Federal Republic of Germany in 1991

\begin{tabular}{|c|l|l|r|r|}
\hline No. & \multicolumn{1}{|c|}{ Federal Land } & Capital & Area in sq. km & Population \\
\hline 1 & City of Berlin & - & 1,200 & $3,400,000$ \\
2 & Brandenburg & Potsdam & 29,100 & $2,500,000$ \\
3 & Thuringia & Erfurt & 16,300 & $2,600,000$ \\
4 & Saxony & Dresden & 18,300 & $4,700,000$ \\
5 & Saxony-Anhalt & Magdeburg & 20,400 & $2,800,000$ \\
6 & Mecklenburg-Vorpommern & Schwerin & 23,600 & $1,900,000$ \\
7 & Baden-Württemberg & Stuttgart & 35,700 & $10,000,000$ \\
8 & Bavaria & Munich & 70,500 & $11,600,000$ \\
9 & City of Bremen & & - & 700,000 \\
10 & Lower Saxony & Hannover & 47,400 & $7,500,000$ \\
11 & City of Hamburg & & - & $1,700,000$ \\
12 & Hessen & Wiesbaden & 21,100 & $5,800,000$ \\
13 & Rhineland-Palatinate & Mainz & 19,800 & $3,800,000$ \\
14 & Rhineland-Northern Westphalia & Düsseldorf & 34,100 & $17,500,000$ \\
15 & Saar & Saarbrucken & 2,600 & $1,100,000$ \\
16 & Schleswig-Holstein & Kiel & 15,700 & $2,600,000$ \\
\hline & Germany & Berlin & 357,000 & $80,200,000$ \\
\hline
\end{tabular}

Source: Nowa Encyklopedia Powszechna 1996: 457.

with a complete collapse of, this time, Nazi Germany. The subsequent territorial verdict, announced after this war in Potsdam, reduced the territory of Germany from 468,700 sq. km to 357,000 sq. $\mathrm{km}$. Hence, the territorial loss amounted to $111,700 \mathrm{sq}$. $\mathrm{km}$. In the consequence of being defeated in two world wars, Germany lost altogether 183,800 sq. km. In relation to the initial state, i.e. as of 1914 , these territorial losses were equivalent to $34 \%$, that is - more than one third of the territory of Germany was incorporated into other countries over the course of the 20th century. Figure 2 shows the geopolitical image of these losses, which concerned predominantly the eastern parts of the country.

The map of Figure 2, which presents a generalized image, allows for identifying the pattern of the German state before the World Warl, then the shape of the territory in the period between 1919 and 1937, and, finally, the current state, resulting from the decisions, taken in 1945. The map shows also the particular areas, lost by Germany to the advantage of its neighbours. The biggest beneficiary is Poland. The majority of the territories, lost by Germany during the 20th century, is now Polish: altogether some $150,000 \mathrm{sq}$. km, of which close to 50,000 sq. km - under the Versailles Treaty, and more than $100,000 \mathrm{sq}$. km due to the decisions, taken in Potsdam. Thus, nearly half of the territory of contemporary Poland is constituted by the areas, which had been integral parts of the German Reich before the World War I. The remaining German territorial losses amounted to more than $30,000 \mathrm{sq}$. $\mathrm{km}$. These areas belong now to France, Belgium, Denmark, Lithuania, Czechia and the Russian Federation. Altogether, this brought a significant decrease of the German demographic and economic potential.

German imperial plans ended with a geopolitical catastrophe. Defeated twice, Germany lost numerous provinces, and this made a strong imprint on the consciousness of the German nation (East Prussia, Silesia, Pomerania, Alsace and Lorraine). Until the World War I these areas had been inhabited by well 


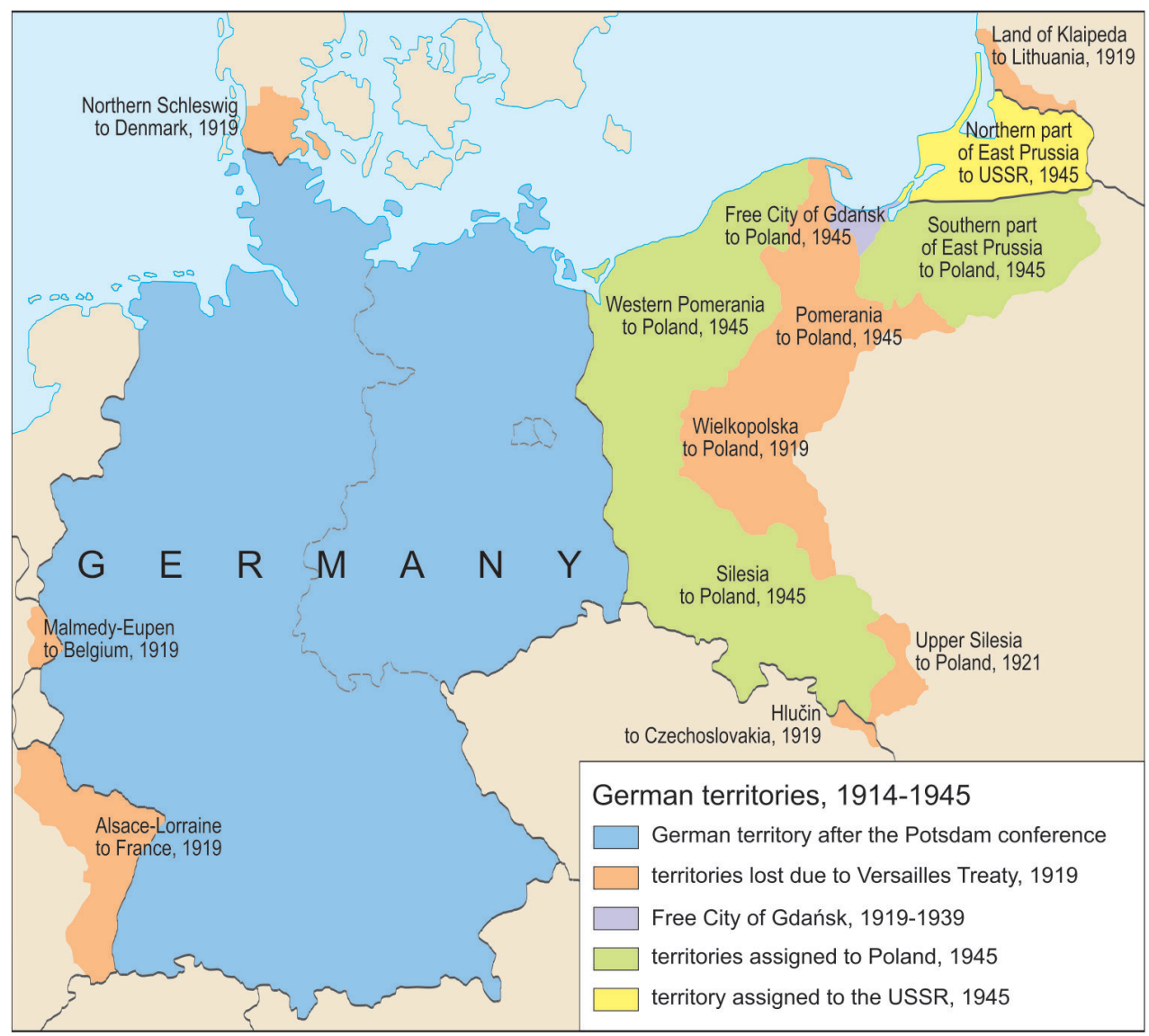

Figure 2. Territorial changes of the German state 1914-1945

over ten million ethnic Germans. The eastern boundary of Germany receded very significantly to the West, away from the line of $\mathrm{Ne}$ man and Prosna rivers, to the Oder-Neisse rivers line. Thereby, the political and legal status was brought back that existed in the Middle Ages. The effects of the secular progress of the German colonization were annihilated, and the achievements of the respective population in terms of civilisation were taken over by the populations, belonging to a different cultural circle (Eberhardt 2010).

The here considered movements of the boundaries and the changes in the political status and state affiliation of the relatively vast territories brought significant geopolitical consequences for the entire Central Europe.
The political domination of Germany was importantly limited, as were the reaches of the German culture and language. All these issues, though, take on increasingly a historical meaning, in the face of the progressing integration of states and nations in the framework of the European Union.

\section{Editors' note:}

Unless otherwise stated, the sources of tables and figures are the authors', on the basis of their own research. 


\section{References}

CZUBiński A. (ed.), 1992. Problem granic i obszaru odrodzonego państwa polskiego 1918-1990. Poznań: Wydawnictwo Uniwersytetu Adama Mickiewicza.

Die beVÖlKerung des Deutschen Reiches nach der VolKSZ̈̈HLUNG VON 1910, 1912. Berlin.

DzIEwoński K., Kosiński L., 1967. Rozwój i rozmieszczenie ludności Polski w XX wieku. Warszawa: Wydawnictwo Naukowe PWN.

EberHardt P., 2008. Projekty aneksyjne Cesarstwa Niemieckiego wobec ziem polskich podczas I Wojny Światowej [in:] P. Eberhardt (ed.), Problematyka geopolityczna ziem polskich, Prace Geograficzne, 218, Warszawa: Instytut Geografii i Przestrzennego Zagospodarowania PAN, pp. 135-150.

Eberhardt P., 2010. Migracje polityczne na ziemiach polskich 1939-1950. Poznań: Instytut Zachodni.

EberHARDT P., 2013. Granice polityczno-administracyjne państwa niemieckiego w XX wieku. Czasopismo Geograficzne, vol. 84, no. 1-2, pp. 3-28.

Hartenstein M., 2006. Die Geschichte der Oder-Neisse Linie. Munich: Olzog.

HAUSER P., 1995. Niemcy wobec perspektywy rozstrzygnięć Konferencji Pokojowej w sprawie zachodniej granicy Polski [in:] Cz. Bloch, Z. Zieliński (eds.), Powrót Polski na mapę Europy, Lublin: Wydawnictwa KUL, pp. 117-146.

Hilgemann W., 1984. Atlas zur deutschen Zeitgeschichte 1918-1968. Munich-Zurich: Piper.

Historia Polski w liczbach. Państwo I SpoteczeńSTwO. vol. 1, 2003. Warszawa: Główny Urząd Statystyczny.

KNAURS LeXIKON A-Z, 1950-1951. Munich: Droemersche Verlagsanstalt.
Kокот J., 1957. Logika Poczdamu. Katowice: Wydawnictwo Śląsk.

LABUdA G., 1974. Polska granica zachodnia. Tysiac lat dziejów. Poznań: Wydawnictwo Poznańskie.

Łossowski P., 2007. Kłajpeda kontra Memel. Problem Kłajpedy. Warszawa: Instytut Historii PAN.

MAJEWSKI P.M., 2000. Edvard Beneš i kwestia niemiecka w Czechach. Warszawa: Wydawnictwo DiG.

Maty Rocznik Statystyczny 1937. Warszawa: Główny Urząd Statystyczny.

ManN G., 2007. Niemieckie dzieje w XIX i XX wieku. Olsztyn: Wspólnota Kulturowa Borussia.

MuszYŃSKI J., 1995. O skrupulatniejsze spojrzenie na terytorium i granice Polski po odzyskaniu przez niq niepodległości. Uwagi w zwiqzku z ksiqżka "Problem granic i obszaru odrodzonego państwa polskiego 1918-1990". Przegląd Zachodni, 1, Poznań, pp. 165-176.

Nowa Encyklopedia Powszechna.Vol. 4, 1996. Warszawa: Wydawnictwo Naukowe PWN.

Perthes J., 1941. Taschen Atlas der Ganzen Welt. Gotha: Justuj Perthes.

Riedel J. (ed.), 1928. Knaurs Welt Atlas. Berlin: Knaur.

SienkieWicz W., HrYciuk G., (eds.), 2008. Wysiedlenia, wypędzenia i ucieczki 1939-1945. Atlas ziem Polski. Warszawa: Demart.

Wituch T., 2001. Terytoria sporne w Europie po 1815 roku. Pułtusk: Wyższa Szkoła Humanistyczna.

ZgórnIAK M., 1966. Przygotowanie wojenne hitlerowskich Niemiec w dobie "Anschlussu" Austrii (XI 1937 - III 1938). Zeszyty Naukowe Uniwersytetu Jagiellońskiego, 140, Prace Historyczne, 17, pp. 183-204.

Ziemie Zachodnie I PóŁnocne W liczBach, 1966. Warszawa: Główny Urząd Statystyczny. 